\title{
Diel Vertical Distribution Patterns of Pelagic Fish Larvae in Yilan Bay, Taiwan
}

\author{
Yi-Chen Wang \\ National Taiwan Ocean University,Keelung City, Taiwan (R.O.C.), live723@mail.ntou.edu.tw \\ Su-Chen Tsai \\ National Taiwan Ocean University,Keelung City, Taiwan (R.O.C.) \\ Wen-Yu Chen \\ Fisheries Agency, Council of Agriculture, Taipei City, Taiwan, R.O.C.
}

Follow this and additional works at: https://jmstt.ntou.edu.tw/journal

Part of the Fresh Water Studies Commons, Marine Biology Commons, Ocean Engineering Commons, Oceanography Commons, and the Other Oceanography and Atmospheric Sciences and Meteorology Commons

\section{Recommended Citation}

Wang, Yi-Chen; Tsai, Su-Chen; and Chen, Wen-Yu (2022) "Diel Vertical Distribution Patterns of Pelagic Fish Larvae in Yilan Bay, Taiwan," Journal of Marine Science and Technology. Vol. 29: Iss. 6, Article 6.

DOI: $10.51400 / 2709-6998.2557$

Available at: https://jmstt.ntou.edu.tw/journal/vol29/iss6/6

This Research Article is brought to you for free and open access by Journal of Marine Science and Technology. It has been accepted for inclusion in Journal of Marine Science and Technology by an authorized editor of Journal of Marine Science and Technology. 


\title{
Diel Vertical Distribution Patterns of Pelagic Fish Larvae in Yilan Bay, Taiwan
}

\author{
Yi-Chen Wang ${ }^{a, *}$, Su-Chen Tsai ${ }^{a}$, Wen-Yu Chen ${ }^{b}$ \\ a Department of Environmental Biology and Fisheries Science, National Taiwan Ocean University, No. 2, Beining Rd., Zhongzheng Dist., \\ Keelung City 202, Taiwan, ROC \\ ${ }^{b}$ Research and Development Section, Fisheries Agency, Council of Agriculture, 6F., No.100, Sec. 2, Heping W. Rd., Zhongzheng Dist., \\ Taipei City 10070, Taiwan, ROC
}

\begin{abstract}
To study the diel migration distribution of larval fish in an area adjacent to the Kuroshio Current, samples were collected from six depths by using a Motoda horizontal net at a fixed station in Yilan Bay on July 30 and 31, 2007. A total of 591 larval fish were collected and assigned to at least 34 families and 57 species. The first five dominant species were Benthosama pterotum (40.95\%), Diaphus B type (12.18\%), Callionymidae spp. (8.46\%), Gobiidae spp. (6.60\%), and Apogonidae spp. (4.0\%). The density of larval fish varied across time. The maximum larval density was 1220.34 individuals $/ 1000 \mathrm{~m}^{3}$ at 19:00, and the minimum larval density was 81.84 ind./1000 $\mathrm{m}^{3}$ at 14:00. The vertical distribution of species accounting for more than $\mathbf{1 0} \%$ of all fish caught was determined by the diurnal and nocturnal migration of the dominant species B. pterotum, which migrated from a depth of $50 \mathrm{~m}$ at night to $200 \mathrm{~m}$ in the afternoon. The distribution models for other species (e.g., Diaphus B type) were also analyzed in this study.
\end{abstract}

Keywords: Vertical distribution, Diel migration, Benthosema pterotum

\section{Introduction}

$\mathrm{L}$ arval fish" is a general term for fish stages between the hatching and free-swimming stages [1]. Fish in this stage cannot sufficiently move by themselves [2]. Because their fins and inner structures are not yet developed, they cannot respond to environmental changes and avoid enemies $[2,3]$. Therefore, the distribution of fish larvae can be easily affected by environmental factors such as fronts $[4,5]$, tides and currents [6], winds [8,9], water depth $[2,10]$, bottom features [11,12], the amount of aquatic plants [13], spawning area and time [11], and differences between species and life stages [2].

Some fish species have diel migration patterns in estuaries [14]. Diel migratory behavior of fish can be caused by the stratified structure of water or can be spontaneous [15-17]. Vertical distribution and migration model variation have been observed among individuals [18-20]. Fish larvae lack the ability to swim [3]; thus, they live among planktonic organisms. Therefore, the discovery of diel vertical migration among larval fish is particularly meaningful for understanding fish behavior and ecology $[21,22]$. Furthermore, information on the vertical distribution of larval fish is crucial for studying the relationship among biology, transportation in current systems, and species survival rates [23]. According to [23]; fish larvae species in the subfamilies of Lampanyctinae and Myctophinae (family of Myctophidae) inhabit different water depths to avoid cannibalism. Moreover, the depth where fish larvae live determines the current routes and distances they are carried over [24,25], which affect resource recruitment in fisheries. Therefore, understanding diel distribution for fish larvae studies

Received 17 February 2020; revised 20 May 2020; accepted 30 June 2020.

Available online 27 December 2021

* Corresponding author.

E-mail address: live723@mail.ntou.edu.tw (Y.-C. Wang). 
is important. However, the diel distribution of larval fish in the Kuroshio Current area has not been widely studied. Thus, this study focused on the diel density, species composition, and growth stage differences of larval fish and oceanographic environmental factors (temperature and salinity) to understand their relationships.

\section{Materials and methods}

This study was conducted from July 30 to 31, 2007, at one fixed station $\left(121^{\circ} 57^{\prime} \mathrm{E}, 24^{\circ} 48^{\prime} \mathrm{N}\right)$ in Yilan Bay, Taiwan (Fig. 1) on the research vessel Ocean Researcher II. To analyze the diel vertical distribution of larval fish across time, the Motoda horizontal net (MTD net; mouth diameter of $0.6 \mathrm{~m}$ and mesh size of $330 \mu \mathrm{m}$ [26]; was used to collect fish larvae from six depths (multilayered simultaneous tows): 5, 50, 100, 150, 200, and $250 \mathrm{~m}$. Tows began at 19:00 (July 30), followed by towing at 01:00 (July 31), 07:00 (July 31 ), 14:00 (July 31), and 19:00 (July 31). A flowmeter (model 438 115, HYDRO-BIOS, Kiel-Holtenau, Germany) was attached to the center of each net mouth to calculate the volume of filtered water. The volume of filtered water $(\mathrm{V})$ was calculated using the following formula:

$$
L=N \times R C
$$

$V=\frac{\pi \times D^{2} \times L}{4}$

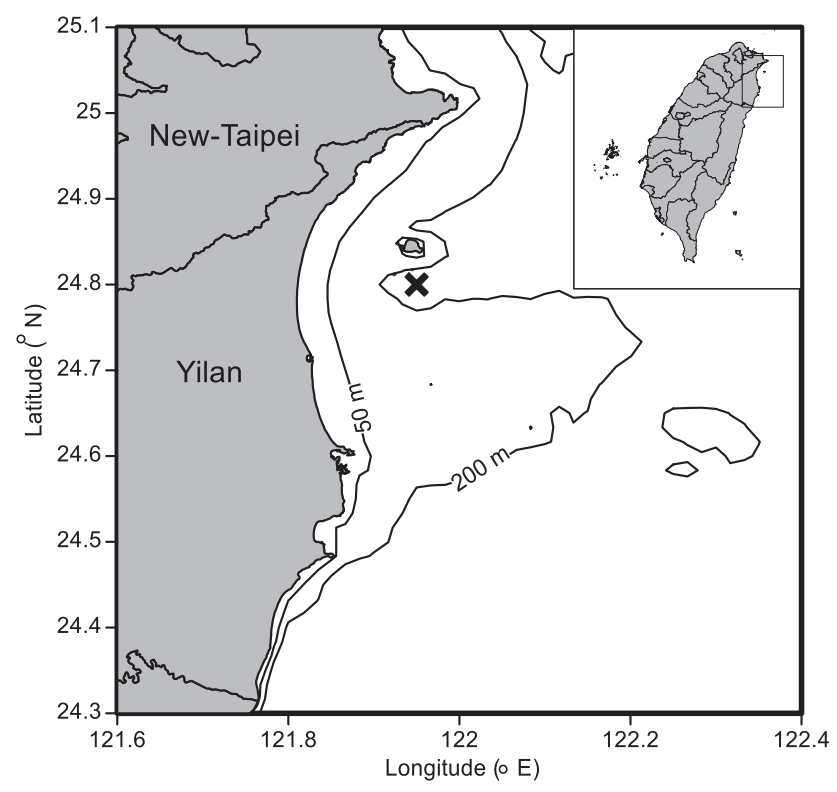

Fig. 1. Location of the study area and sampling site $(\mathrm{X})$ in Yilan Bay, Taiwan. where $L$ is the net towing distance $(\mathrm{m}), N$ is the number of revolutions, $R C$ is the pitch of the impeller at $0.3, \pi$ is the ratio of the circumference of a circle to its diameter, and $D$ is the diameter of the net mouth.

The MTD net is a type of vertical multiple closing plankton sampler [26]. It can sample at a desired depth, and the net mouth can be closed using a plumb to prevent contaminated materials from upper zones from entering into the net. However, the MTD net still had a slight contamination problem during sampling in the first few minutes of towing; thus, we attempted to maintain an oblique wire angle (close to $45^{\circ}$ ) to reduce the depth error [23]. After towing horizontally for $30 \mathrm{~min}$ at a speed of $1 \mathrm{kn}$, a signal hammer was dispatched to close the net mouth to avoid catching fish in other layers while retrieving the net. An advantage of the MTD net is simultaneous multilayer sampling, which can help us analyze the diel vertical movement of fish larvae simultaneously. Specimens were immediately stored in $5 \%$ formalin and brought to the laboratory for identification. Larval fish were selected from the total samples and identified to the species level or lowest possible taxonomic level in the laboratory in accordance with [27] descriptions. Diaphus of the slender and stubby type belonged to Diaphus A and B types in this study, respectably. Postanal melanophores and body length were identifying features. More than two fish in a family or genus were identified as many species (spp.). Damaged fish that were difficult to identify were treated as unknown species and were not included in the analysis. Four larval developmental stages were identified: preflexion larvae (pr), flexion larvae (fl), postflexion larvae (po), and juvenile (Ju; [3]. The body lengths of larval fish were measured to the nearest $0.01 \mathrm{~mm}$ by using the CCD Vision Image Hunter System. Notochord length was measured for preflexion-stage larvae, and the standard length was measured for flexion- and postflexion-stage larvae.

A conductivity-temperature-depth profiler (SBE 9/11, Sea-Bird Electronics Inc., Bellevue, WA, USA) was cast from the Ocean Researcher II during each sampling period to collect temperature and salinity information from the surface to a depth of approximately $250 \mathrm{~m}$. All collected data were transformed into figures based on time, temperature, and depth by using SBE Data Processing (v7.22.1, Sea-Bird Electronics Inc.). These environmental data were displayed using Surfer 9 (Golden Software Inc., Golden, CO, USA).

The collected data were used to calculate the density of larval fish, Shannon-Wiener diversity index $\left(\mathrm{H}^{\prime} ;[28]\right.$, and Pielou's evenness index $\left(\mathrm{J}^{\prime} ;[29]\right.$. 
Fish larval density is expressed as the number of individuals per $1000 \mathrm{~m}^{3}$ (ind./1000 $\mathrm{m}^{3}$ ). The Shannon-Wiener diversity index was used to understand the population variation of larval fish at different time points and water depths. Pielou's evenness index was used to calculate the similarity in the number of fish between species.

\section{Results}

\subsection{Oceanographic condition}

Oceanographic condition sampling was conducted five times during the research period. From the surface to a depth of $250 \mathrm{~m}$, temperature and salinity ranged from $12.95{ }^{\circ} \mathrm{C}$ to $29.63{ }^{\circ} \mathrm{C}$ and from 33.75 to $34.62 \mathrm{psu}$, respectively (Fig. 2). Thermocline and halocline locations varied over time. The thermocline location ranged between 50 and $100 \mathrm{~m}$ and was observed in shallower areas at dawn and in the morning and in deeper areas at night. The halocline location ranged from 30 to $100 \mathrm{~m}$, and salinity approached stability at a depth of $100 \mathrm{~m}$. In addition, temperature and salinity differences among the sampling time points were minor.

\subsection{Larval density and composition}

A total of 591 larvae representing 34 families and 57 species were collected over five sampling time points. The density of larval fish varied over time. The maximum density was $1,220.34$ ind./1000 $\mathrm{m}^{3}$

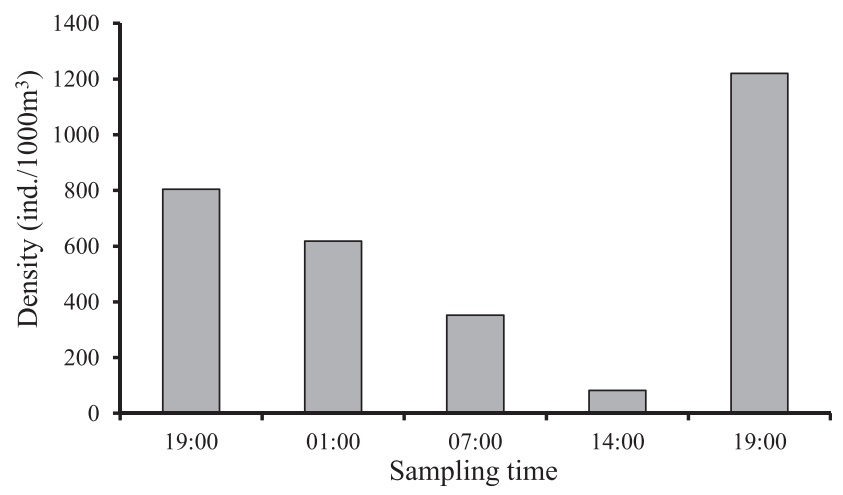

Fig. 3. Total density of fish larva at each sampling time.

(collected at 19:00 on July 31), and the minimum density was 81.84 ind. $/ 1000 \mathrm{~m}^{3}$ (collected at 14:00 on July 31; Fig. 3). Moreover, larval density did not change with variations in thermocline and halocline locations (Fig. 4). Larval fish assembled above the thermocline and halocline locations $(50 \mathrm{~m})$ at night but moved below them $(100 \mathrm{~m})$ in the morning. In the afternoon, the abundance of larval fish formed two peaks $(50 \mathrm{~m}$ and $200 \mathrm{~m}$ ).

In this study, the first five dominant species/ families were Benthosema pterotum, Diaphus B type, Callionymidae spp., Gobiidae spp., and Apogonidae spp., which accounted for $40.95 \%, 12.18 \%, 8.46 \%$, $6.60 \%$, and $4.0 \%$ of the total catch, respectively. The diversity index ranged from 1.79 to 2.52 . The most diverse sample was collected at 19:00 on July 30 , and the least diverse sample was collected at 14:00 on

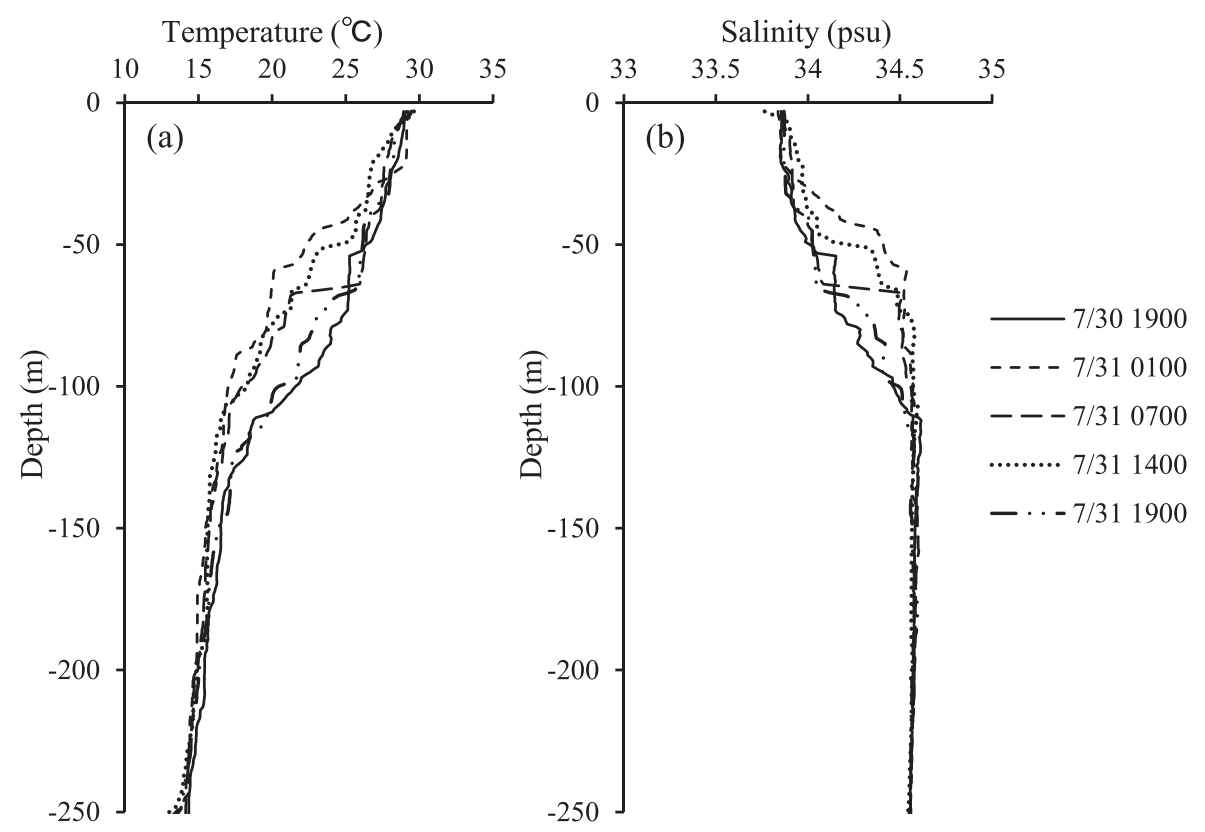

Fig. 2. Vertical structure of (a) temperature $\left({ }^{\circ} \mathrm{C}\right)$ and (b) salinity (psu) at each sampling time. 


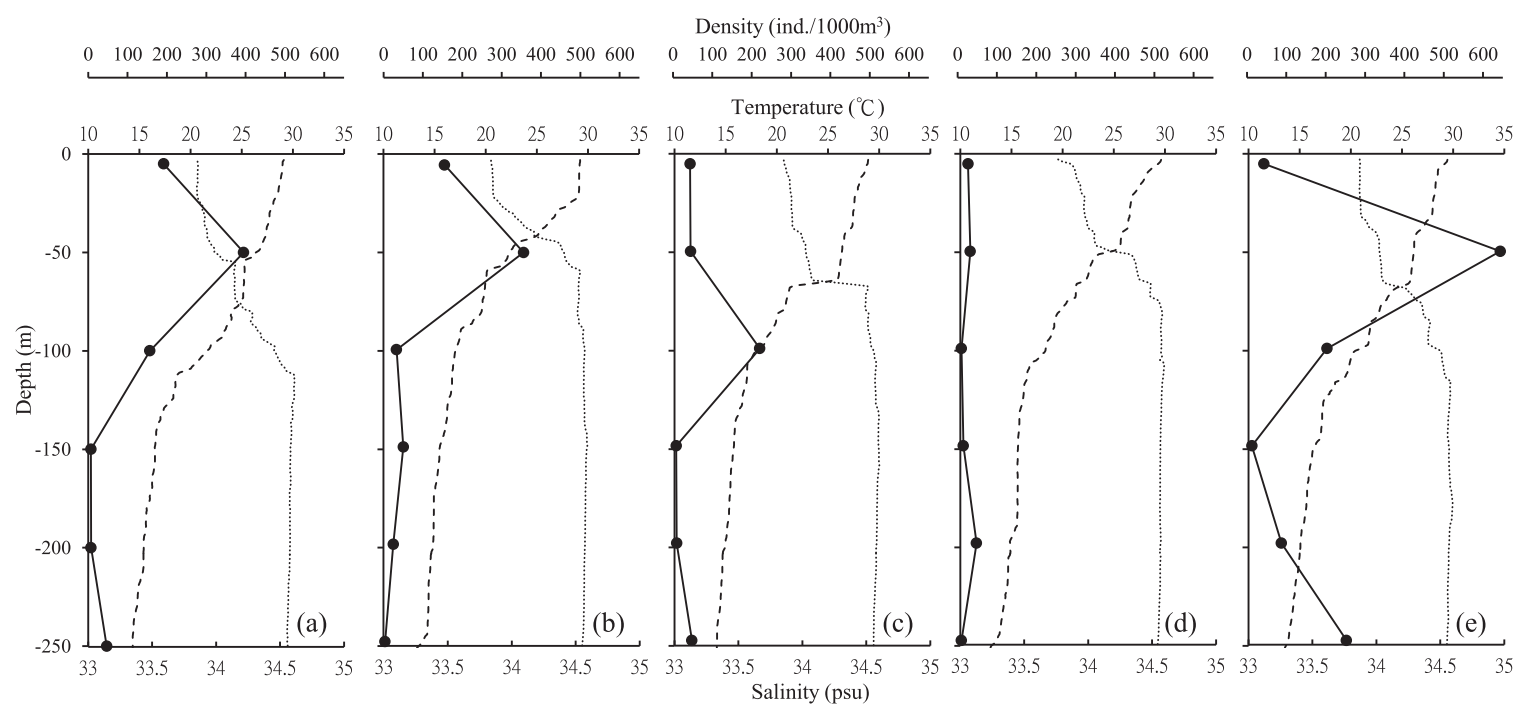

Fig. 4. Vertical distribution and density of larval fish (solid lines) in relation to vertical temperature $\left({ }^{\circ} \mathrm{C}\right.$, dotted lines) and salinity ( $p$ su, dashed lines) profiles in Yilan Bay: (a) 19:00 on July 30, (b) 01:00 on July 31, (c) 07:00 on July 31, (d) 14:00 on July 31, and (e) 19:00 on July 31.

July 31 . Moreover, the evenness index was between 1.44 and 1.90 and was the highest at 07:00 on July 31 . It was lowest at 01:00 on July 31 .

\subsection{Vertical distribution of fish}

Regarding vertical distribution (Fig. 4), most larval fish inhabited water depths between the surface and $100 \mathrm{~m}$. At night, the following high fish density was observed at a depth of $50 \mathrm{~m}: 394.78$ ind.$/ 1000 \mathrm{~m}^{3}$ at 19:00 on July $30,354.96$ ind./1000 $\mathrm{m}^{3}$ at $01: 00$ on July 31 , and 640.00 ind./1000 $\mathrm{m}^{3}$ at 19:00 on July 31. At 07:00, larval fish moved to depths between 50 and $150 \mathrm{~m}$, and the maximum density observed at $100 \mathrm{~m}$ was 216.89 ind. $/ 1000 \mathrm{~m}^{3}$ (July 31). At 14:00 on July 31, the density of larval fish at a depth of $50 \mathrm{~m}$ decreased rapidly to $<40$ ind. $/ 1000 \mathrm{~m}^{3}$. As illustrated in Fig. 4, another density peak formed at $200 \mathrm{~m}$ and was greater than that at $50 \mathrm{~m}$ at the same time. Furthermore, the characteristics of the vertical distribution of larval fish at 19:00 on July 31 were identical to those at 19:00 on July 30 .

The vertical distribution of species accounting for more than $10 \%$ of all fish caught was analyzed. Two distribution models were developed for assessing the vertical distribution of larval fish: a vertical migration model (e.g., B. pterotum) and a stable model (e.g., Diaphus B type). As detailed in Fig. 5a, a high density of $B$. pterotum individuals moved from a depth of $50 \mathrm{~m}$ at night (19:00 and 01:00) to a depth of $100 \mathrm{~m}$ in the morning (07:00) and $200 \mathrm{~m}$ in the afternoon (14:00). This phenomenon comprised the vertical migration model. Regarding temperature and salinity, B. pterotum could cross the thermocline. As detailed in Fig. 5b, Diaphus B type individuals were distributed at depths of $50-100 \mathrm{~m}$ regardless of time. Therefore, their distribution may be nonmigration. The body lengths of B. pterotum were measured at each sampling time (Fig. 6). The most common length was $<4 \mathrm{~mm}$; however, fish longer than $8 \mathrm{~mm}$ accounted for more than $60 \%$ of the sample and became the most abundant at 14:00.

\section{Discussion and conclusions}

\subsection{Oceanographic condition}

According to the vertical distribution model by [30]; the temperature of the Kuroshio Current in Taiwan's eastern region is the highest at the surface and decreases with depth to $500 \mathrm{~m}$, after which the temperature remains stable. Maximum salinity and minimum salinity were observed at depths of approximately 200 and $500 \mathrm{~m}$, respectively. Because the sampling station for this study was in Yilan Bay, which is near the Kuroshio Current, the oceanographic structure should be similar to that of the Kuroshio Current. However, because of the effects of fresh water, the oceanographic properties in Yilan Bay differed slightly from those in the Kuroshio Current. Nevertheless, this study revealed that temperature and salinity were stable at the study site, and the effect of fresh water was negligible. Differences were observed in the depths and slope of the thermocline and halocline. 


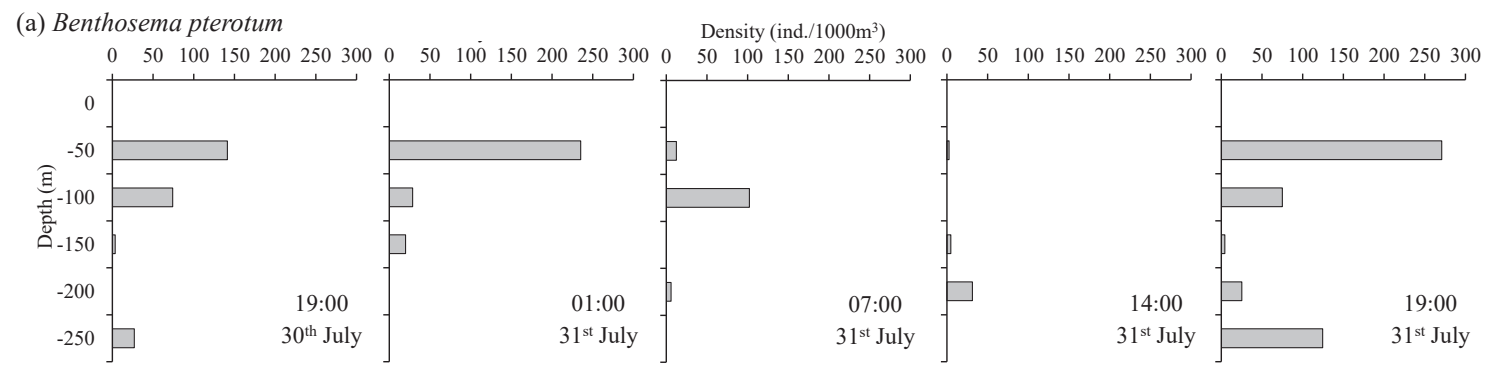

(b) Diaphus B type

Density (ind. $/ 1000 \mathrm{~m}^{3}$ )

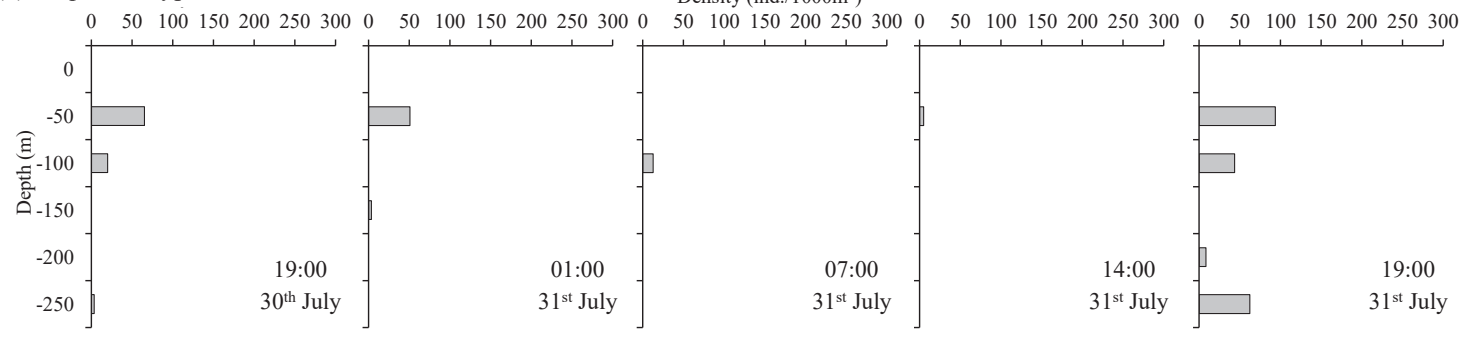

Fig. 5. Vertical distribution and density (individuals $/ 1000 \mathrm{~m}^{3}$ ) of (a) Benthosema pterotum and (b) Diaphus B type at each sampling time.

\subsection{Species composition and diel vertical distribution}

The species composition in the Kuroshio Current is simpler than that in coastal areas [15]. Myctophidae, Gonostomatidae, and Phosichthyidae are the most dominant families, and other species are less prevalent $[15,23,31-34]$. In this study, B. pterotum and Diaphus B type of the Myctophidae family accounted for $53.13 \%$ of all specimens. The remaining $46.87 \%$ was represented by 33 other families and 55 taxa. Therefore, the study site was considerably affected by the Kuroshio Current.

Regarding variation in larval fish abundance, a general cycle of high density at night, declining density at dawn and in the morning, and low density in the afternoon was observed. This was similar

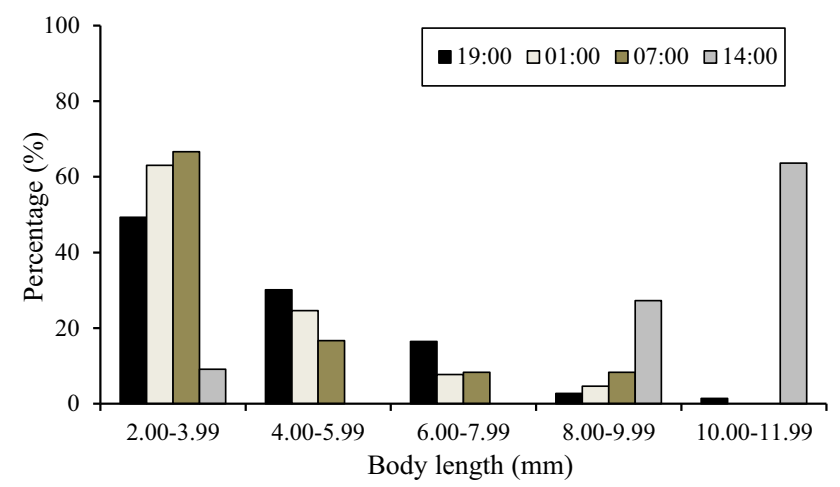

Fig. 6. Body length of Benthosema pterotum at each sampling time. to previous findings in which larval fish were more numerous at night than during the day [15]. Therefore [15], conjectured that this phenomenon is related to the diel migration of pelagic ichthyoplankton. The density of larval fish is affected by water movement [35]. However, the present study suggested that the density variation of larval fish in Yilan Bay was caused by the diel vertical migration of B. pterotum [36]. used the hydroacoustic method (38-kHz scientific echo sounding system) to observe the movement of the deep scattering layer (DSL) in Yilan Bay (the bottom depth was approximately $350 \mathrm{~m})$. The results indicated that the DSL descended before sunrise (stayed at 180 to $280-\mathrm{m}$ depth in the daytime) and ascended before sunset (stayed at 10 to $150-\mathrm{m}$ depth in the nighttime). Lee et al. [37] reported on the diel variations of the sound scattering layer by using a scientific echo sounder in northeastern Taiwan (the bottom depth was approximately $800 \mathrm{~m}$ ). The DSL was observed at 10-120-m depth at nighttime and remained in the deep layer (400-500-m and 600-700-m depths) during the daytime. Kao et al. [38] found two DSLs during the daytime at depths of 80-130 and 130-230 $\mathrm{m}$, and the DSLs remained at a depth of 10-80 $\mathrm{m}$ at nighttime in Yilan Bay (the average bottom depth was approximately $300 \mathrm{~m}$ ). Furthermore, the depth of both DSLs may be influenced by changes in water temperature. Benthosema pterotum is a part of the DSL and migration, along with other fauna [39]. DSL movement may be in response to the diel vertical migration of $B$. pterotum given the 
high density at night in the surface water and in the daytime in deep water.

We discovered a variation of density between two samplings at 19:00 on July 30 and 31, but no significant difference was found in the species composition. After further analysis, the major density variated were from B. pterotum, Diaphus B type, and some coastal species (such as Callionymidae spp., Engraulidae spp., and Scombridae spp.) between the two samplings. The density of B. pterotum and Diaphus B type was higher on July 31 than on July 30 , particularly at depths of $50 \mathrm{~m}$ and $200-250 \mathrm{~m}$. The density of other species was higher on July 31 than on July 30 at a depth of 50-100 m. Smith and Suthers [40] reported that the highest larval density was associated with the interface between the mixed layer and the thermocline. The interface between the mixed layer and the thermocline may represent a region of optimum growth and feed for larval fish, with maximum chlorophyll concentrations. Furthermore, the location of the thermocline or halocline appears to regulate the vertical distribution of ichthyoplankton in coastal and oceanic waters [41,42]. In our study, the locations of the thermocline and halocline were slightly shallower on July 31 than on July 30 . This indicated that shallower locations of the thermocline and halocline may concentrate larvae in the surface water for easy collection. Therefore, we sampled more on July 31 than on July 30 . However, we still require additional information for further investigation of the distribution of the deepwater layer (more than $300 \mathrm{~m}$ or more samplings layers between 0 and $100 \mathrm{~m}$ ) in larvae and the possible influence of hydrographic conditions in Yilan Bay to explain this phenomenon.

Auth and Brodeur [43] reported that most larval fish inhabit water shallower than $100 \mathrm{~m}$, and their maximum density is at $50 \mathrm{~m}$ of depth [44]. In this study, most larval fish resided in water shallower than $100 \mathrm{~m}$, and the highest density was observed at $50 \mathrm{~m}$. These findings are consistent with those of [43]. Because MTD nets are difficult to operate when sampling in the ocean, few studies on the vertical distribution of larval fish have been conducted. Sassa and Konishi [45] investigated a vertical distribution model for Trachurus japonicus larvae in the southern part of the East China Sea by using the MTD net. There was no evidence of either diel vertical migration for the fish larvae of $T$. japonicus. However, many other species exhibit diel vertical migration behavior in the larval stage [45]. Such behavior may be exhibited by larvae by themselves or caused by natural conditions such as lighting, temperature, and food sources [14,45].

Most lanternfish migrate extensively from mesoplagic depths to shallower waters at night, and some even reach the surface $[17,46]$. The reported habitat depth of B. pterotum adults is $130-500 \mathrm{~m}$ during the day, and it ranges from the surface to a depth of approximately $300 \mathrm{~m}$ at night [47-49]. However, these results are for fish in the juvenile to adult stage and not for larval fish. Wang and Lee [50] indicated that salinity, temperature, zooplankton biomass, and chlorophyll concentration affect $B$. pterotum larval horizontal distribution on the continental shelf of the southern East China Sea in the summer. This species moves to water with low temperature and salinity as it gradually grows up. However, in this study, the density of larval fish varied for the dominant species, B. pterotum, and this study found that B. pterotum can move across the thermocline and halocline. Therefore, we suggested that the vertical migration of $B$. pterotum was the outcome of ontogenetic movement and was not related to temperature or salinity. Differences in distribution affected by the temperature and salinity may result from horizontal distribution and not vertical distribution. In addition, B. pterotum in all samples had a length of $2.18-11.56 \mathrm{~mm}$ in our study. Most myctophid species become adults at a length of 12-19 $\mathrm{mm}$ [51], which indicates that all samples were in the larval to juvenile stage in our study. Wang and Lee [50] suggested that the density of $B$. pterotum in juveniles does not significantly differ according to different sampling depths and between daytime and nighttime. This result suggested that the diel vertical migration of $B$. pterotum should commence in the juvenile stage. Willis and Pearcy [52] indicated that lanternfish larvae with a length of $30-40 \mathrm{~mm}$ can migrate $30 \mathrm{~m}$ upward at night. Our study results are similar to those of these studies, and lanternfish larvae with a length of $8 \mathrm{~mm}$ can migrate $200 \mathrm{~m}$ downward during the day.

Diaphus larvae belong to the Myctophidae family and may have diel vertical migration in the ocean. In previous studies, various vertical distribution patterns have been shown for Diaphus larvae, such as $D$. theta and D. gigas, which are migrants and show clear day-night habitat separation [53]. The habitat depths of the slender type of Diaphus do not differ between day and night, which indicates no vertical migration $[17,54]$. The day-night differences in the catches of $D$. garmani do not significantly indicate the possibility of diel vertical migration [17]. However, in our study, we perceived Diaphus B type individuals to be nonmigrants distributed at depths of 50-100 m regardless of time. Similar results stating that this species is abundant in the upper layer (between 0 and $100 \mathrm{~m}$ ) were reported by $[17,23]$. However, more than 10 Diaphus species may have belonged to Diaphus B type in this study because identifying this genus is difficult due to the presence of various postanal 
melanophores [55,56]. This may be a reason why Diaphus B type did not show clear day-night habitat separation. If we can identify more species in this genus in the future, a clear diel vertical distribution pattern may appear.

In summary, the results indicated that the environment in Yilan Bay was considerably affected by the Kuroshio Current. Benthosema pterotum and Diaphus B type in the Myctophidae family were determined to be dominant species. The density temporal variation of larval fish in Yilan Bay was caused by the diel vertical migration of $B$. pterotum. We suggested that the diel vertical migration of $B$. pterotum was the outcome of ontogenetic movement and was not related to temperature or salinity.

\section{Acknowledgments}

We are grateful to the Ministry of Science and Technology (NSC 94-2611-M-019-009) for partially funding this research. In addition, we thank the crew of the vessel Ocean Researcher II of National Taiwan Ocean University for collecting samples and environmental data. Finally, we wish to thank Wallace Academic Editing for editing this manuscript.

\section{References}

[1] Leis JM, Rennis DS. The larvae of Indo-Pacific coral reef fishes. New South Wales University Press \& University of Hawaii Press; 1983. p. 269.

[2] Wang YT, Tzeng WN. Tempora succession and spatial segregation of clupeoid larvae in the coastal waters off the Tanshui River Estuary, northern Taiwan. Mar Biol 1997;129: 23-32.

[3] Kendall Jr AW, Ahlstrom EH, Moser HG. Early life history stages of fishes and their characters. Ontogeny and systematic of fish. National Marine Fisheries Service; 1984. p. 11-22. Special Publication No. 1.

[4] Largier JL. Estuarine fronts: how important are they? Estuaries 1993;16:1-11.

[5] Grioche A, Koubbi P. A preliminary study of the influence of a coastal frontal structure on ichthyoplankton assemblages in the Englis Channel. ICES J Mar Sci 1997;54:93-104.

[6] Kingsford MJ, Suthers IM. The influence of tidal phase on patterens of ichthyoplankton abundance in the vicinity of an estuarine front, Botany Bay, Austualia. Estuar Coast Shelf Sci 1996;43:33-54.

[8] Shanks AL. Vertical migration and cross shelf dispersal of larval Cancer spp. and Randallia ornate (Crustacea: Brachyura) off the coast of southern California. Mar Biol 1986;92:189-99.

[9] Verdier-Bonnet C, Carlotti F, Rey C, Bhaud M. A model of larval dispersion coupling wind-driven currents and vertical larval behaviour: application to the recruitment of the annelid Owenia fusiformis in Banyuls Bay, France. Mar Ecol Prog Ser 1997;160:217-31.

[10] Hopkins TL, Gartner JV. Resource-partitioning and predation impact of a low-latitude myctophid community. Mar Biol 1992;114:185-97.

[11] Sabates A. Distribution pattern of larval fish populations in the Northwestern Mediterranean. Mar Ecol Prog Ser 1990;59: 75-82.
[12] Humphries P, Potter IC. Relationship between the habitat and diet of three species of atherinids and three species of gobies in a temperate Australian estuary. Mar Biol 1993;116: 193-204.

[13] Humphries P, Potter IC, Loneragan NR. The fish community of the shallows of a temperate Australian estuary: relationship with density of the seagrass Ruppia megacarpa. Estuar Coast Shelf Sci 1992;34:325-46.

[14] Neilson JD, Perry RI. Diel vertical migrations of marine fishes: an obligate or facultative process? Adv Mar Biol 1990; 26:115-68.

[15] Tzeng WN. Preliminary studies on species composition of fish larvae and juveniles in the kuroshio waters adjacent to Taiwan with reference to water mass and diurnal variation. Acta Oceanogr Taiwanica 1989;22:102-15.

[16] Lyczkowski-Shultz J, Steen Jr JP. Diel vertical distribution of red drum Sciaenops ocellatus larvae in the north-central Gulf of Mexico. Fish Bull USA 1991;89:631-41.

[17] Sassa C, Kawaguchi K, Hirota Y, Ishida M. Distribution patterns of larval myctophid fish assemblages in the subtropical-tropical waters of the western North Pacific. Fish Oceanogr 2004;13(4):267-82.

[18] Brewer GD, Kleppel GS. Diel vertical distribution of fish larvae and their prey in nearshore waters of southern California. Mar Ecol Prog Ser 1986;27:217-26.

[19] Heath MR, Henderson EW, Baird DL. Vertical distribution of herring larvae in relation to physical mixing and illumination. Mar Ecol Prog Ser 1988;47:211-28.

[20] Tzeng WN, Wang YT. Hydrography and distribution dynamics of larval and juvenile fishes in the coastal waters of the Tanshui River estuary, Taiwan, with reference to estuarine larval transport. Mar Biol 1993;116:205-17.

[21] Moser HG, Richards WJ, Cohen DM, Fahay MP, Kendall AW, Richardson SL. Ontogeny and systematics of Fishes. Based on an international symposium dedicated to the memory of Elbert Haivor Ahlstrom. Spec. Publ. No. 1. Am Soc Ichthyol Herpetol 1984.

[22] Ruple D. Gobioidei: development. P. 582-587. In: Ontogeny and systematics of fishes. Spec. Publ. No. 1. Amer. Soc. Ichthyol. Herpetol; 1984.

[23] Sassa C, Moser HG, Kawaguchi K. Horizontal and vertical distribution patterns of larval myctophid fishes in the Kuroshio Current region. Fish Oceanogr 2002;11(1): $1-10$.

[24] Kim H, Sugimoto T. Transport of larval jack mackerel (Trachurus japonicus) estimated from trajectories of satellitetracked drifters and advective velocity fields obtained from sequential satellite thermal images in the eastern East China Sea. Fish Oceanogr 2002;11(6):329-36.

[25] Komatsu K. Temporal variation of surface wind-drifted current observed by drifting buoys in the East China Sea. Bull Fish Res Agency 2003;7:14-23.

[26] Motoda S. Devices of simple plankton apparatus. Mem Fac Fish Hokkaido Univ 1959;7(1-2):73-94.

[27] Okiyama M. An atlas of the early stage fishes in Japan. 2nd ed. Tokyo: Tokai University press; 2014. p. 1639.

[28] Shannon CE, Weaver W. The mathematical theory of communication. Chicago: University Illinois Press; 1963. p. $29-124$.

[29] Omori M, Ikeda T. Methods in marine zooplankton ecology". New York: John Wiley \& Sons; 1984. p. 332.

[30] Chung YC, Yin HC. Radium-226 in the kuroshio water near taiwan: results from the KEEP and KEEP-MASS programs. TAO 1995;6:47-63.

[31] John HC. Drift of larval fishes in the Ocean. Results and problems from previous studies and proposed field experiment. In: McClave JD, Arnold GP, Dodson JJ, Neill WH, editors. Mechanisms of migration in fishes. New York: Plenum Press; 1984. p. 39-60.

[32] Cowen RT, Hare JA, Fahay MP. Beyond hydrography: can physical processes explain larval fish assemblages within the middle Atlantic Bight? Bull Mar Sci 1993;53:567-87. 
[33] Chiu TS, Hsyu YH. Interannual variation of ichthyoplankton density and species composition in the waters off northeastern Taiwan. Mar Biol 1994;119:441-8.

[34] Olivar MP, Beckley LE. Influence of the Agulhas current on the distribution of lanternfish larvae off the southeast coast of Africa. F Plankton Res 1994;16:1759-80.

[35] Chiu TS. Variation of ichthyoplankton density across the Kuroshio edge exchange area with implications as to the water masses. TAO 1991;2:147-62.

[36] Chou SC, Lee MA, Lee KT. Diel vertical movement of the deep scattering layer on the continental slope of I-Lan Bay, Taiwan. Fish Sci 1999;65(5):694-9.

[37] Lee MA, Chao MH, Weng JS, Lan YC, Lu HJ. Diel distribution and movement of sound scattering layer in Kuroshio waters, northeastern Taiwan. J Mar Sci Technol 2011;19(3):253-8.

[38] Kao SC, Lee MA, Iida K. Diel change in acoustic characteristics and zooplankton composition of the sound scattering layer in I-Lan Bay in northeastern Taiwan. J Mar Sci Technol 2016;24(2):282-91.

[39] Catul V, Gauns M, Karuppasamy PK. A review on mesopelagic fishes belonging to family Myctophidae. Rev Fish Biol Fish 2011;21(3):339-54.

[40] Smith KA, Suthers IM. Displacement of diverse ichthyoplankton assemblages by a coastal upwelling event on the Sydney shelf. Mar Ecol Prog Ser 1999;176:49-62.

[41] Davis TLO, Jenkins GP, Young JW. Die1 patterns of vertical distribution in larvae of southern bluefin Thunnus maccoyii, and other tuna in the East Indian Ocean. Mar Ecol Prog Ser 1990;59:63-74.

[42] Palomera I. Vertical distribution of eggs and larvae of EngrauL is encrasicolus in stratified waters of the western Mediterranean. Mar Biol 1991;111:37-44.

[43] Auth TD, Brodeur RD. Distribution and community structure of ichthyoplankton off the coast of Oregon, USA, in 2000 and 2002. Mar Erol Prog Ser 2006;319:199-213.

[44] Olivar MP, Sabatés A. Vertical distribution of fish larvae in the north-west Mediterranean Sea in spring. Mar Biol 1997; 129(2):289-300.

[45] Sassa C, Konishi Y. Vertical distribution of jack mackerel Trachurus japonicus larvae in the southern part of the East China Sea. Fish Sci 2006;72:612-9.
[46] Dypvik E, Klevjer TA, Kaartvedt S. Inverse vertical migration and feeding in glacier lanternfish (Benthosema glaciale). Mar Biol 2012;159(2):443-53.

[47] Gjøsaeter J. Mesopelagic fish, a large potential resource in the Arabian Sea. Deep-Sea Res PT I 1984;31(6):1019-35.

[48] Valinassab T, Pierce GJ, Johannesson K. Lantern fish (Benthosema pterotum) resources as a target for commercial exploitation in the Oman Sea. J Appl Ichthyol 2007;23(5): $573-7$.

[49] Sassa C, Tsukamoto Y, Yamamoto K, Tokimura M. Spatiotemporal distribution and biomass of Benthosema pterotum (pisces: Myctophidae) in the shelf region of the East China Sea. Mar Ecol Prog Ser 2010;407:227-41.

[50] Wang YC, Lee MA. Ontogenetic habitat differences in Benthosema pterotum during summer in the shelf region of the southern East China Sea. Deep Sea Res Part II Top Stud Oceanogr 2020:104739.

[51] Moser HG, Ahlstrom EH. The role of larval stages in systematic investigations of marine teleosts: the Myctophidae, a case study. The Early Life History of Fish. Berlin, Heidelberg: Springer; 1974. p. 605-7.

[52] Willis JM, Pearcy WG. Spatial and temporal variations in the population size structure of three lanternfishes (Myctophidae) off Oregon, USA. Mar Biol 1980;57(3):181-91.

[53] Watanabe H, Moku M, Kawaguchi K, Ishimaru K, Ohno A Diel vertical migration of myctophid fishes (Family Myctophidae) in the transitional waters of the western North Pacific. Fish Oceanogr 1999;8(2):115-27.

[54] Watanabe H, Sassa C, Ishida M. Late winter vertical distribution of mesopelagic fish larvae in the Kuroshio Current region of the western North Pacific. Bull Jpn Soc Fish Oceanogr 2010;74:153-8.

[55] Wang JTM, Chen CT. A review of lanternfishes (families: Myctophidae and Neoscopelidae) and their distributions around Taiwan and the Tungsha Islands with notes on seventeen new records. Zool Stud 2001;40(2):103-26.

[56] Hsieh $\mathrm{CH}$, Chiu TS. Summer spatial distribution of copepods and fish larvae in relation to hydrography in the northern Taiwan Strait. Zool Stud 2002;41:85-98. 